RNA 23: 1946-1960 (2017)

\title{
Corrigendum: ASC1 and RPS3: new actors in 18S nonfunctional rRNA decay
}

\section{KELLY A. LIMONCELLI, CHRISTOPHER N. MERRIKH, and MELISSA J. MOORE}

In the above-mentioned article, the gel images in Figure 3A were inadvertently duplicated. The updated version is shown below and has been corrected online. The authors apologize for this error but note that it does not in any way change the conclusions drawn from the data.
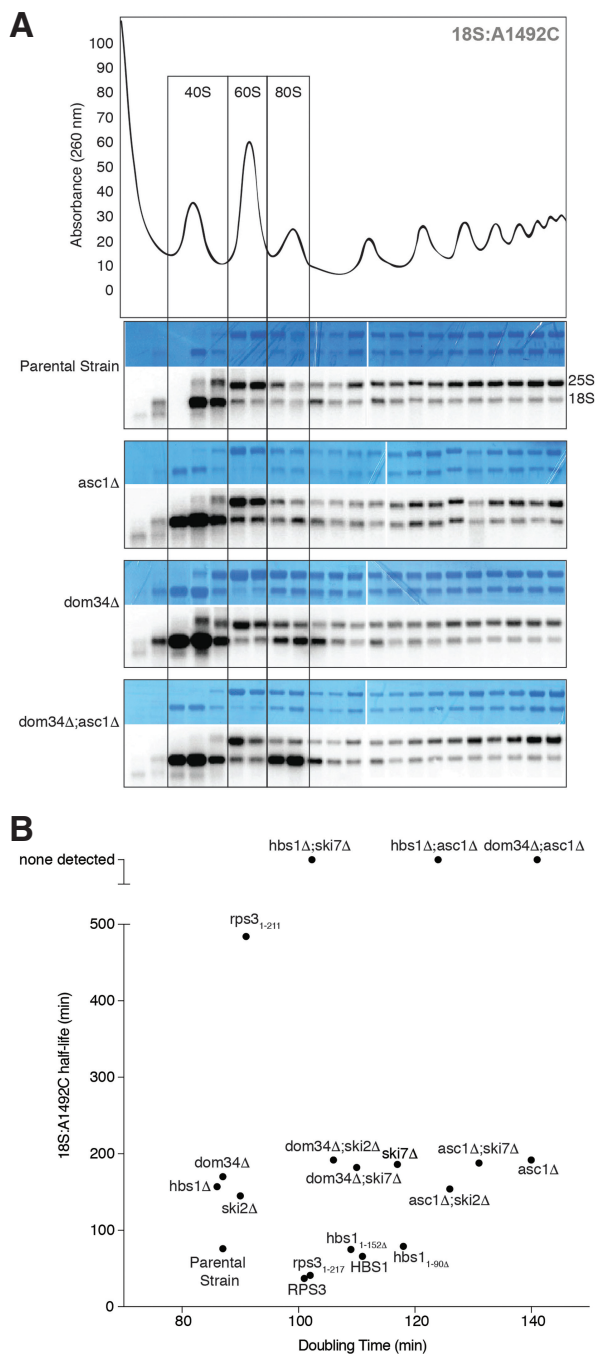

FIGURE 3. (A) Polysome profiles. (Top) Representative sucrose gradient trace for the parental strain. (Bottom) Methylene Blue stains and Northern blots of sucrose gradient fractions for the parental, asc1 $1 \Delta$, dom $34 \Delta$, and asc1 $\Delta$; dom $34 \Delta$ strains harboring the 18S:A1492C plasmid. Boxes show positions of $40 \mathrm{~S}, 60 \mathrm{~S}$, and $80 \mathrm{~S}$ ribosomes. (B) Scatter plot of mean 18S:A1492C half-lives $(n=3)$ versus mean growth rates (doubling time; $n=3$ ) of various yeast strains used in current study.

doi: $10.1261 /$ rna.066159.118 

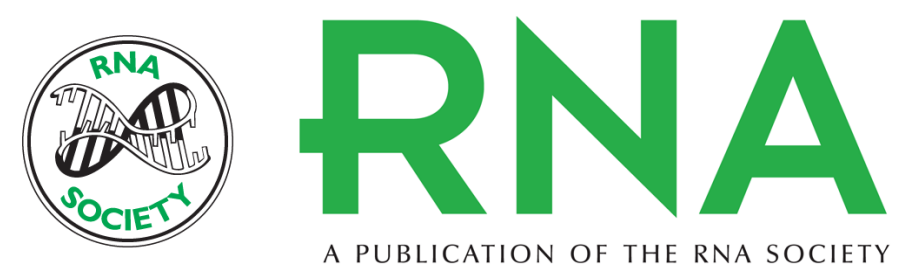

A PUBLICATION OF THE RNA SOCIETY

\section{Corrigendum: $A S C 1$ and RPS3: new actors in 18S nonfunctional rRNA decay}

Kelly A. Limoncelli, Christopher N. Merrikh and Melissa J. Moore

RNA 2018 24: 620

Related Content

Open Access

License

Email Alerting

Service
ASC1 and RPS3: new actors in 18S nonfunctional rRNA decay

Kelly A. Limoncelli, Christopher N. Merrikh and Melissa J. Moore

RNA December , 2017 23: 1946-1960

Freely available online through the RNA Open Access option.

Receive free email alerts when new articles cite this article - sign up in the box at the top right corner of the article or click here.

To subscribe to RNA go to:

http://rnajournal.cshlp.org/subscriptions 